\title{
Social instigation and repeated aggressive confrontations in male Swiss mice: analysis of plasma corticosterone, CRF and BDNF levels in limbic brain areas
}

\author{
Instigação social e confrontos agressivos repetidos em camundongos Swiss \\ machos: análise de corticosterona plasmática e dos níveis de CRF e BDNF em \\ áreas cerebrais límbicas
}

\begin{abstract}
Paula Madeira Fortes, ${ }^{1,2}$ Lucas Albrechet-Souza, ${ }^{1,2}$ Mailton Vasconcelos, ${ }^{1,2}$ Bruna Maria Ascoli, ${ }^{2}$ Ana Paula Menegolla, ${ }^{1}$
\end{abstract} Rosa Maria M. de Almeida ${ }^{1}$

\begin{abstract}
Introduction: Agonistic behaviors help to ensure survival, provide advantage in competition, and communicate social status. The resident-intruder paradigm, an animal model based on male intraspecific confrontations, can be an ethologically relevant tool to investigate the neurobiology of aggressive behavior.

objectives: To examine behavioral and neurobiological mechanisms of aggressive behavior in male Swiss mice exposed to repeated confrontations in the resident intruder paradigm.

Methods: Behavioral analysis was performed in association with measurements of plasma corticosterone of mice repeatedly exposed to a potential rival nearby, but inaccessible (social instigation), or to 10 sessions of social instigation followed by direct aggressive encounters. Moreover, corticotropin-releasing factor (CRF) and brain-derived neurotrophic factor (BNDF) were measured in the brain of these animals. Control mice were exposed to neither social instigation nor aggressive confrontations.

Results: Mice exposed to aggressive confrontations exhibited a similar pattern of species-typical aggressive and non-aggressive behaviors on the first and the last session. Moreover, in contrast to social instigation only, repeated aggressive confrontations promoted an increase in plasma corticosterone. After 10 aggressive confrontation sessions, mice presented a nonsignificant trend toward reducing hippocampal levels of CRF, which inversely correlated with plasma corticosterone levels. Conversely, repeated sessions of social instigation or aggressive confrontation did not alter BDNF concentrations at the prefrontal cortex and hippocampus.

Conclusion: Exposure to repeated episodes of aggressive encounters did not promote habituation over time. Additionally, CRF seems to be involved in physiological responses to social stressors.

Keywords: Aggression, social instigation, corticosterone, CRF, BDNF.
\end{abstract}

\section{Resumo}

Introdução: Comportamentos agonísticos ajudam a garantir a sobrevivência, oferecem vantagem na competição e comunicam status social. O paradigma residente-intruso, modelo animal baseado em confrontos intraespecíficos entre machos, pode ser uma ferramenta etológica relevante para investigar a neurobiologia do comportamento agressivo.

Objetivos: Analisar os mecanismos comportamentais e neurobiológicos do comportamento agressivo em camundongos Swiss machos expostos a confrontos repetidos no paradigma residente-intruso.

Métodos: A análise comportamental foi realizada em associação com medidas de corticosterona plasmática em camundongos expostos repetidamente a um rival em potencial próximo, porém inacessível (instigação social), ou a 10 sessões de instigação social seguidas de encontros agressivos diretos. Além disso, o fator de liberação de corticotrofina (CRF) e o fator neurotrófico derivado do cérebro (BNDF) foram medidos no encéfalo desses animais. Camundongos controles não foram expostos à instigação social ou confrontos agressivos.

Resultados: Os camundongos expostos a confrontos agressivos exibiram um padrão semelhante de comportamentos agressivos e não agressivos típicos da espécie na primeira e na última sessão. $\mathrm{Em}$ contraste com instigação social apenas, confrontos agressivos repetidos promoveram aumento na corticosterona plasmática. Após 10 sessões de confrontos agressivos, os camundongos apresentaram uma tendência não significativa de redução dos níveis de CRF no hipocampo, que se correlacionaram inversamente com os níveis plasmáticos de corticosterona. Por outro lado, sessões repetidas de instigação social ou confronto agressivo não alteraram as concentrações de BDNF no córtex pré-frontal e hipocampo.

Conclusão: A exposição a episódios repetidos de encontros agressivos não promoveu habituação ao longo do tempo. Adicionalmente, o CRF parece estar envolvido nas respostas fisiológicas aos estressores sociais.

Descritores: Agressão, instigação social, corticosterona, CRF, BDNF.

${ }^{1}$ Instituto de Psicologia, Universidade Federal do Rio Grande do Sul (UFRGS), Porto Alegre, RS, Brazil. ${ }^{2}$ Hospital de Clínicas de Porto Alegre (HCPA), Porto Alegre, RS, Brazil.

Submitted Oct 24 2016, accepted for publication Feb 152017.

Suggested citation: Fortes PM, Albrechet-Souza L, Vasconcelos M, Ascoli BM, Menegolla AP, de Almeida RM. Social instigation and repeated aggressive confrontations in male Swiss mice: analysis of plasma corticosterone, CRF and BDNF levels in limbic brain areas. Trends Psychiatry Psychother. 2017;39(2):98-105. http://dx.doi.org/10.1590/2237-6089-2016-0075 


\section{Introduction}

Social systems and social stressors differ between species but in general social animals form dominancebased hierarchies. ${ }^{1}$ In this context, aggression is an adaptive behavioral trait important for establishing dominance as well as competition for mating partners, food, and territories. ${ }^{2}$ While a certain level of aggression is supposed to be beneficial for survival, abnormal aggression can be detrimental. In fact, increase in aggressiveness is a common occurrence in a variety of psychiatric disorders. ${ }^{3,4}$

Laboratory models of social stress include the visible burrow system, crowding stress, and the resident-intruder paradigm. ${ }^{5-7}$ Social stress models are particularly useful because they are considered ethologically relevant. ${ }^{8}$ Furthermore, most of the stress faced by humans occurs in a social context. ${ }^{9}$ Although preclinical research has produced important descriptions of aggression and provided a solid basis for analysis of the neurobiology of aggressive behavior, the degree of similarity across species, neural systems, behavioral expression, and outcomes of aggression remain unclear.

Limbic regions such as the prefrontal cortex (PFC) and hippocampus are involved in innate social behaviors and response to social stress. ${ }^{10}$ These areas seem to be critical for emotional and cognitive functions such as social recognition, fighting, mating, fear, or motivated behaviors. ${ }^{10}$ The PFC and hippocampus have been identified as particularly important in the modulatory control of subcortical circuits that mediate aggressive and impulsive behaviors ${ }^{11,12}$; the components of these circuits include the medial amygdala, hypothalamus and the periaqueductal grey. ${ }^{13-22}$ Indeed, PFC lesions promote an increase in aggressive behavior in rats. ${ }^{23}$ Similarly, lesions involving frontal and temporal brain areas have been demonstrated to dramatically increase aggressiveness in humans. ${ }^{24}$

It is already known that repeated episodes of social confrontation promote long-lasting neuroadaptation in rodents that are defeated in the resident-intruder paradigm. ${ }^{25}$ However, less is known about functional, as well as neuroadaptive, changes that occur in the brain of aggressive residents exposed to repeated episodes of social interactions. In this study, male resident Swiss mice were repeatedly exposed to either a potential rival nearby, but inaccessible (social instigation), ${ }^{12}$ or to 10 sessions of social instigation followed by direct aggressive encounters. Controls were exposed to neither social instigation nor aggressive confrontations. After the last session, we measured plasma corticosterone (CORT), the stress neuropeptide corticotropin-releasing factor (CRF) and brain-derived neurotrophic factor
(BDNF) in limbic brain areas. CRF was measured in the hippocampus and hypothalamus, areas previously related to aggression and behavioral and physiological responses to stress. ${ }^{26,27}$ BDNF was measured in the PFC and hippocampus, brain regions associated with behavioral planning and affective behaviors. ${ }^{28}$

The primary role of CRF is to activate the hypothalamic-pituitary-adrenal (HPA) axis by acting on receptors in the pituitary and promoting the release of adrenocorticotropic hormone (ACTH) into the portal blood system. ${ }^{27} \mathrm{ACTH}$ stimulates the release of CORT from the adrenal glands - CORT plays several roles in mediating appropriate responses to stress and also exerts a negative feedback control of the HPA axis. ${ }^{29}$ Extrahypothalamic distribution of CRF includes neuronal populations in the amygdala, $^{30,31}$ hippocampus, $^{32}$ and locus coeruleus. ${ }^{33}$ CRF and its related peptides exert central function and mediate several behavioral and physiological responses to stress, ${ }^{34-38}$ including anxiety-like behavior and some aspects of aggressiveness. ${ }^{35,39-43}$

The present study tested the hypothesis that BDNF may underlie, at least in part, experience-induced neuroplasticity in resident mice exposed to repeated sessions of agonistic interactions. BDNF is a molecule involved in the regulation of diverse biological functions, ranging from neuronal survival and differentiation during development to synaptic plasticity and cognitive behavior in the adult ${ }^{44}$; it has also been demonstrated to be a critical mediator of changes in social motivation. ${ }^{45}$ In both rodents and humans, BDNF disruption is associated with neurobehavioral alterations and psychiatric disorders. ${ }^{44}$

\section{Methods}

\section{Subjects}

Adult Swiss mice weighed $25-30 \mathrm{~g}$ ( 8 weeks old) upon arrival were housed in polycarbonate cages $(30 \times 19 \times$ $15 \mathrm{~cm}$ ) with pine shavings as bedding. Rodent laboratory chow and water were available ad libitum through stainless steel wire mesh lids. Male mice were assigned as residents $(n=24)$ or intruders $(n=20)$. Each resident mouse was pair-housed with a female Swiss mouse ( $n$ =24), whereas intruders were kept in groups of 6 per cage. The vivarium of the Animal Experimentation Unit at Hospital de Clínicas de Porto Alegre (Porto Alegre, RS, Brazil) was maintained on a $12 \mathrm{~h}$ light/dark cycle, $22 \pm 2{ }^{\circ} \mathrm{C}$ temperature, and $50-60 \%$ humidity. The experiments were performed during the light phase, between 09:00 and 12:00 a.m. Experimental procedures were conducted in accordance with Brazilian Federal Law no. 11.794/2008, which regulates the scientific 
use of animals. The project was approved by the Ethics Committee on Animal Use of the Animal Experimentation Unit at Hospital de Clínicas de Porto Alegre.

\section{Tubal-ligation surgery}

Female mice were tubally ligated using antiseptic techniques and standard surgical procedure. ${ }^{46}$ Briefly, mice were anesthetized with ketamine $(120 \mathrm{mg} / \mathrm{kg})+$ xylazine (30 mg/kg, intraperitoneally [i.p.]) and placed in the right lateral decubitus position. Then, a dorsal incision (approximately $1.0 \mathrm{~cm}$ ) was made, the ovary was located, and the ends of the uterine horn were tied off using absorbable sutures. The oviduct was located and severed using a micro-scissor. All reproductive structures were repositioned back in the abdominal cavity, and the abdominal incision was closed with absorbable sutures and the skin with non-absorbable sutures. ${ }^{47}$ The same procedure was performed on the left side. Mice were injected with tramadol (10 $\mathrm{mg} / \mathrm{kg}$, i.p.) immediately after the surgery and during the next 3 consecutive days $(12 / 12 \mathrm{~h})$ to provide analgesia. Female mice were singlehoused and allowed to recover for 7 days before being paired with a resident male. Upon termination of the experiment, females were euthanized with an overdose of ketamine $(300 \mathrm{mg} / \mathrm{kg})+$ xylazine $(30 \mathrm{mg} / \mathrm{kg}$, i.p. $)$.

\section{Experimental design}

The experimental design is shown in Figure 1. Male resident mice were tested after being pair-housed with a female for 3 weeks. Before the sessions, the female cage mate was removed from the resident's cage and kept in a holding cage. Resident mice were divided into the following experimental groups: 1 ) controls (CT): an empty perforated acrylic tube $(18 \times 6 \mathrm{~cm})$ was placed into the resident's cage for $5 \mathrm{~min}$; 2) social instigation group (SI): a perforated acrylic tube $(18 \times 6 \mathrm{~cm})$ containing an intruder mouse was placed into the resident's cage for 5 min. Mice had visual, auditory, and olfactory contact, but the resident had no direct access to the intruder; 3 ) social instigation + aggressive confrontation group (SI+AC): a perforated acrylic tube $(18 \times 6 \mathrm{~cm})$ containing an intruder mouse was placed into the resident's cage for $5 \mathrm{~min}$, followed by actual confrontation without any protection. The aggressive encounter was terminated 5 min after the resident initiated the first attack bite or at $5 \mathrm{~min}$ if the resident failed to attack. ${ }^{48}$ Residents were exposed to 10 sessions of social instigation or social instigation + aggressive confrontation, twice in a week, with a minimum interval of $72 \mathrm{~h}$ between sessions. Mice that did not present bite attacks against the intruder in the first two sessions were excluded from the experiment.

\section{Aggressive and non-aggressive behaviors exhibited by resident mice during the first (T1) and last (T10) agonistic encounters}

T1 and T10 were video-recorded and later coded by two independent researchers using the Observer $\mathrm{XT}$ software (Noldus, v.9.0.436, Wageningen, The Netherlands). The measurements assigned by the two observers agreed with each other $\left(r^{2}=0.94\right)$. The frequency of aggressive behaviors was measured, including attack bites, chasing, lateral threats, sniffing, and tail rattling, as well as the latency of the first attack bite. The frequency or duration of non-aggressive behaviors, including grooming, rearing, and walking, was also evaluated.

\section{Plasma CORT analysis before the resident-intruder encounters (baseline) and after T10}

Resident mice had blood samples collected from the submandibular vein 5 days before the resident-intruder encounters (baseline) and immediately after T10, using disposable sterile lancets. Samples were centrifuged for 10 min at $4^{\circ} \mathrm{C}$ and 4,000 revolutions/min. Blood plasma was extracted and frozen at $-80^{\circ} \mathrm{C}$ for subsequent dosages. Plasma CORT was assessed using commercial ELISA kits

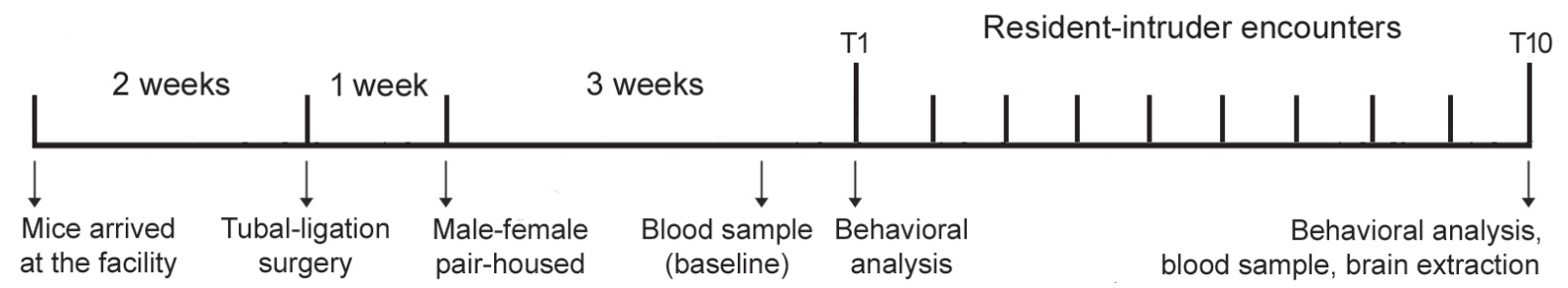

Figure 1 - Experimental design. Aggressive and non-aggressive behaviors were assessed during the first (T1) and last (T10) residentintruder encounters. Blood samples were collected 5 days before the first resident-intruder encounter (baseline) and immediately after T10 for plasma corticosterone analysis. After the last blood collection, brains were extracted for CRF and BDNF measurements. 
(Enzo Life Science, Farmingdale, NY, USA). Detection levels were $32-20 \mathrm{pg} / \mathrm{ml}$, according to the manufacturer.

\section{Brain CRF and BDNF measured after T10}

After the last blood collection, resident mice were rapidly anesthetized with isoflurane and euthanized by decapitation. Brains were quickly removed, thoroughly washed in isotonic saline solution, and dissected on ice. The PFC, hippocampus, and hypothalamus were localized according to a brain atlas ${ }^{49}$ and removed. Brain tissue samples were homogenized (weight/ volume, 1:10) with ice-cold $0.1 \mathrm{M}$ phosphate buffer $(\mathrm{pH} 7.4)$, with the addition of protease inhibitor cocktail (Sigma-Aldrich, St. Louis, MO, USA). Homogenates were centrifuged at $2,000 \mathrm{~g}$ for $5 \mathrm{~min}$, and aliquots of supernatants were separated and stored at $-80^{\circ} \mathrm{C}$ until further analyses. CRF in the hippocampus and hypothalamus were determined using a CRF mouse ELISA assay kit (My ELISA kits, St. Petersburg, FL, USA). BDNF in the PFC and hippocampus were measure by sandwich-ELISA, according to the manufacturer's instructions using specific monoclonal antibodies (R\&D Systems Inc., Minneapolis, MN, USA).

\section{Statistical analyses}

Statistical analyses were performed using STATISTICA version 6.0. The data are reported as mean \pm standard error of mean. Frequency and duration of aggressive and non-aggressive behaviors on T1 and T10 were analyzed with the Student $t$-test for dependent samples. Plasma CORT levels were analyzed using two-way analysis of variance (ANOVA) with repeated measures followed

Table 1 - Aggressive and non-aggressive behaviors exhibited by male resident mice during the first (T1) and the last (T10) social instigation + aggressive confrontation session.

\begin{tabular}{lll}
\hline & T1 & T10 \\
\hline $\begin{array}{l}\text { Aggressive behaviors } \\
\text { Latency to first bite* }\end{array}$ & $16.7 \pm 6.2$ & $7.1 \pm 3.1$ \\
Bites $^{+}$ & $21.4 \pm 2.8$ & $16.5 \pm 3.6^{\ddagger}$ \\
Chasing $^{+}$ & $11.7 \pm 2.2$ & $10.7 \pm 1.8$ \\
Lateral threat $^{+}$ & $4.3 \pm 1.2$ & $1.9 \pm 0.3$ \\
Sniffing $^{+}$ & $17.6 \pm 3.6$ & $12.0 \pm 3.4$ \\
Tail rattle $^{+}$ & $14.0 \pm 3.2$ & $9.9 \pm 2.6$ \\
Non-aggressive behaviors $^{*}$ & & \\
Grooming $^{+}$ & $5.1 \pm 1.1$ & $6.1 \pm 1.5$ \\
Rearing* $^{*}$ & $49.8 \pm 11.3$ & $36.8 \pm 7.8$ \\
Walking* & $35.4 \pm 7.1$ & $25.5 \pm 2.3$ \\
\hline
\end{tabular}

Data presented as mean \pm standard error of mean.

* Duration in seconds; ${ }^{+}$frequency.

${ }^{\ddagger} p<0.05$ compared to T1 $(n=8)$. by post-hoc comparisons using the Newman-Keuls multiple-range test. CRF and BDNF concentrations were analyzed with one-way ANOVA. A linear least-square regression was conducted to determine the relationship between plasma CORT $(\mathrm{ng} / \mathrm{ml})$ and hippocampal CRF $(\mathrm{pg} / \mathrm{ml})$. Statistical significance was set at $\mathrm{p}=0.05$. For the behavioral experiments, each group contained eight animals, and six-seven were randomly used for hormonal and neurochemical measurements.

\section{Results}

The frequency or duration of aggressive and nonaggressive behaviors exhibited by male resident mice during T1 and T10 is shown in Table 1 . The Student $t$-test for dependent samples revealed a significant decrease in the frequency of bites during T10 compared to T1 $(t=3.11, p<0.05)$. No significant differences were observed between T1 and T10 in any other behavioral category evaluated (values of $t$ varying from 0.05 to $2.21 ; p>0.05$ in all cases).

Plasma CORT measurements obtained at baseline and after T10 are shown in Figure 2. Two-way ANOVA with repeated measures revealed significant differences between groups $\left(F_{2,17}=4.55, \mathrm{p}<0.05\right)$, sessions $\left(F_{1,17}\right.$ $=35.85, \mathrm{p}<0.0001)$, and the interaction between these factors $\left(F_{2,17}=4.36, \mathrm{p}<0.05\right)$. Post-hoc analyses indicated a significant increase in plasma CORT in mice exposed to aggressive confrontations (SI+AC), compared to baseline levels, control animals, and mice exposed to social instigation only (SI).

CRF levels in the hippocampus and hypothalamus after T10 are presented in Figure 3. One-way ANOVA



Figure 2 - Plasma corticosterone levels ( $\mathrm{ng} / \mathrm{ml}$ ) measured in controls (CT), mice exposed to social instigation only (SI), or social instigation + aggressive confrontations (SI+AC). Blood samples were collected before the resident-intruder encounters (baseline) and after the last session (T10). Data presented as mean \pm standard error of mean. * Compared to baseline, CT and $\mathrm{SI}$ in the same session. $\mathrm{p}<0.05, \mathrm{n}=6-7$ mice per group. 
revealed no significant differences between the groups in both areas $\left(F_{2,17}=1.66\right.$ and 0.37 , respectively; $\mathrm{p}>$ 0.05 in both cases). However, in the hippocampus, the $\mathrm{SI}+\mathrm{AC}$ group presented a decrease of $32 \%$ in CRF levels compared to control mice, and $42.5 \%$ compared to SI. Also, there was a significant negative linear relationship between plasma CORT and hippocampal CRF levels ( $r^{2}$ $=-0.52, \mathrm{p}<0.05$, Figure 4).

BDNF levels in the PFC and hippocampus after T10 are presented in Figure 5. One-way ANOVA revealed no significant differences between the groups in both areas $\left(F_{2,17}=1.07\right.$ and 1.23 , respectively; $p>0.05$ in both cases).

\section{Discussion}

In this study, male Swiss mice exposed to repeated aggressive inter-male confrontations exhibited a similar pattern of species-typical aggressive and non-aggressive behavior on the first and last sessions. Moreover, the current procedures showed that direct confrontations

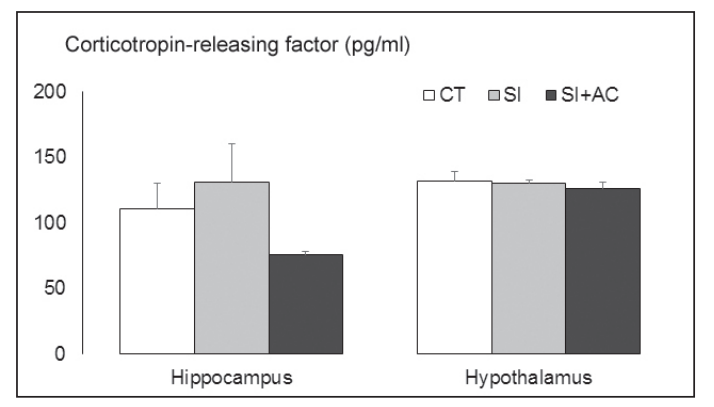

Figure 3 - Corticotropin-releasing factor levels $(\mathrm{pg} / \mathrm{ml}$ ) measured in the hippocampus and hypothalamus of controls (CT), mice exposed to social instigation only (SI), or social instigation + aggressive confrontations (SI+AC). Data presented as mean \pm standard error of mean, $n=6-7$ mice per group.

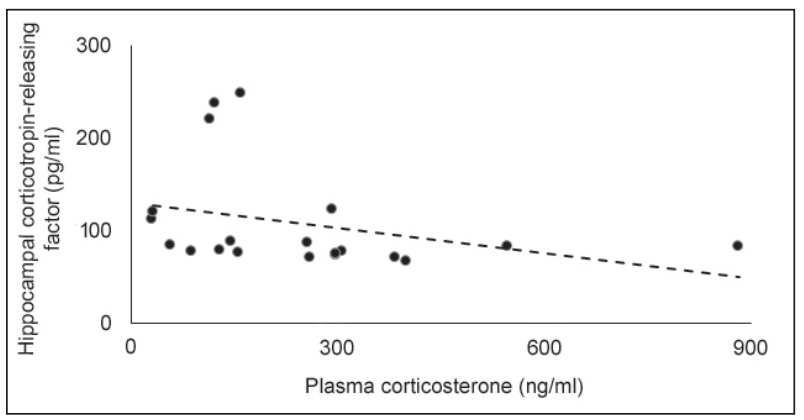

Figure 4 - Plasma corticosterone $(\mathrm{ng} / \mathrm{ml})$ plotted as a function of hippocampal corticotropin-releasing factor $(\mathrm{pg} / \mathrm{ml})$; the dotted line represents the linear fit $\left(r^{2}=-0.52\right)$. $\mathrm{p}<0.05, \mathrm{n}=$ 6-7 mice per group. engendered an activation of the HPA axis during T10, suggesting that exposure to repeated episodes of aggressive encounters does not promote habituation over time. Additionally, after the last aggressive confrontation, mice presented a non-significant trend toward reducing hippocampal levels of CRF, which was negatively correlated with plasma CORT.

The activation of the HPA axis found in the present study is not a surprise, since aggressive encounters involve considerable risks for both resident and intruder. Either of the fighting parties can suffer injuries, and both loose energy reserves that may become crucial in a subsequent challenge. ${ }^{50}$ In agreement with our neuroendocrinal results, male mice exposed to a paradigm of repeated experience of winning in a social conflict have been demonstrated to present increased levels of anxiety in the elevated plus-maze test. ${ }^{26}$

Increases in plasma glucocorticoids during a confrontation have been suggested to facilitate behaviors that are predominant for the animal in that specific context. ${ }^{51}$ Indeed, brain mineralocorticoid receptor blockade during the first aggressive encounter inhibits subsequent propensity for violence in rats. ${ }^{52}$ Thus, both offensive and defensive forms of aggression might respond to reductions in the glucocorticoid release normally associated with the stress of either challenge or conspecific attack, raising the possibility that treatments reducing the systemic activation of the HPA axis may affect aggressiveness.

Repeated sessions of social instigation, which is assumed to enhance the "aggressive arousal" of the resident male, ${ }^{53}$ did not induce significant increases in CORT levels, suggesting that the mobilization of the HPA axis depends on direct confrontations, at least in the protocol used here. Importantly, the basal concentration

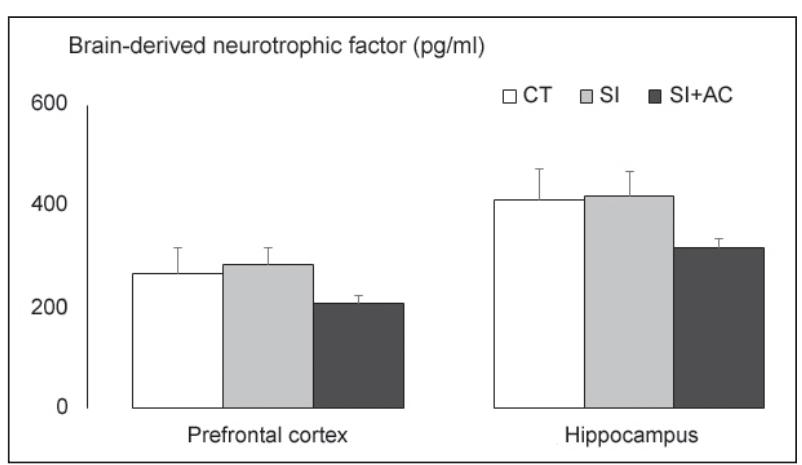

Figure 5 - Brain-derived neurotrophic factor levels $(\mathrm{pg} / \mathrm{ml})$ measured on the prefrontal cortex and hippocampus of controls (CT), mice exposed to social instigation only (SI), or social instigation + aggressive confrontations (SI+AC). Data presented as mean \pm standard error of mean, $n=6-7$ mice per group. 
of plasma CORT in this study (mean $=31.3 \mathrm{ng} / \mathrm{mL}$ ) is consistent with others. ${ }^{54}$

In a study using male rats defeated in the residentintruder paradigm and measuring several neuropeptides in the brain, the authors found a decrease in CRF levels only in the hippocampus, suggesting a depressive-like state in submissive animals. ${ }^{55}$ In the present study, even though aggressive confrontations did not promote a significant main effect on brain $\mathrm{CRF}_{\text {, resident mice }}$ showed a trend toward reducing this neuropeptide in the hippocampus when compared to controls and mice exposed to social instigation only (reduction of $35.5 \%$ and $45.5 \%$, respectively). Thus, it is possible that CRF in the hippocampus may be more involved in emotional and cognitive functions rather than in submissive or aggressive behavior. Interestingly, we found a negative correlation between hippocampal CRF and plasma CORT, suggesting that CRF may be involved in physiological responses to social stressors. Further investigation, however, is required before a mechanistic explanation of hippocampal CRF and plasma CORT can be proposed.

The hypothalamus, more specifically its paraventricular nucleus, is the origin of the HPA axis, whose activation culminates with the release of glucocorticoids from the adrenal glands. ${ }^{27}$ Interestingly, in our experiment, after the last aggressive confrontation, mice presented an increase of plasma CORT without changing hypothalamic levels of CRF. A possible explanation for this apparent discrepancy could be that CRF and CORT present distinct temporal profiles of release. Thus, we may have collected the blood samples and extracted the brains at a time point when hypothalamic CRF had already stimulated ACTH release, but returned to basal levels. The stress response has classically been characterized by two temporal "waves" of stress mediator actions. The first one includes rapid actions of noradrenaline, serotonin, dopamine and CRF, promoting vigilance, alertness, appraisal of the situation and the choice of an optimal strategy to face the challenge. These events are followed by alterations of gene expression and cell function promoting sustained and adaptive stress responses attributed to glucocorticoids. ${ }^{56}$

Finally, increase in hippocampal levels of BDNF in resident hamsters has been suggested to evidence that behaviors associated with aggression and with winning a fight involve plastic mechanisms important to encode spatial representations. ${ }^{57}$ Differently from our study, however, those animals were submitted to a single social interaction session. Thus, changes in BDNF levels may occur after the initial agonistic encounters, which may help to explain the lack of changes in BDNF in the present study. Moreover, aggression-induced cortical activation seems to be especially strong in mice selected for high aggressive behavior. ${ }^{16,58} \mathrm{~A}$ limitation of this study is that we measured brain BDNF only after 10 resident-intruder sessions (social instigation only or social instigation + aggressive confrontation), when neuronal adaptations may be already stablished.

\section{Conclusion}

The present results extend our current knowledge about the neurobiology of aggressiveness by evaluating neurobiological mechanisms of species-typical aggressive behavior in male Swiss mice exposed to repeated sessions of agonistic encounters. The behavioral repertoire and the increase in plasma CORT after 10 aggressive confrontations indicate that resident mice do not present habituation over time. These findings support the idea that treatments reducing the systemic activation of the HPA axis may affect aggressiveness. ${ }^{51}$ Contrary to our expectation, resident mice presented a non-statistically significant but substantial decrease of hippocampal CRF after the last confrontation, which correlated negatively with plasma CORT. Understanding the neuroadaptations that occur after successive episodes of social conflict may provide valuable insights into normal and abnormal forms of aggression and, ultimately, lead to effective approaches to control inappropriate aggressiveness in humans and other animals.

\section{Acknowledgements}

This research was supported by Conselho Nacional de Desenvolvimento Científico e Tecnológico (CNPq). Lucas Albrechet-Souza was supported by Coordenação de Aperfeiçoamento de Pessoal de Nível Superior (CAPES; CSF-PAJT 88887.096822/2015-00). The authors would like to thank Dr. Flávio Kapczinski, Fabiola Meyer, Tuane Garcez and Marta Cioato for providing helpful assistance during the development of this study.

\section{Disclosure}

No other conflicts of interest declared concerning the publication of this article.

\section{References}

1. Blanchard RJ, McKittrick CR, Blanchard DC. Animal models of social stress: effects on behavior and brain neurochemical systems. Physiol Behav. 2001;73:261-71. 
2. Koolhaas JM, Bohus B. Animal models of human aggression. In: Boulton AA, Baker GB, Martin-Iverson MT, editors. Animal models in psychiatry. II. New York: Humana Press; 1992. p. 249-71.

3. Réale,D, Martin J, Coltman DW, Poissant J, Festa-Bianchet M. Male personality, life-history strategies and reproductive success in a promiscuous mammal. J Evol Biol. 2009;22:1599-607.

4. Watters J, Sih A. The mix matters: behavioural types and group dynamics in water striders. Behaviour. 2005;142:1417-31.

5. Armario A, Castellanos JM, Balasch J. Effect of crowding on emotional reactivity in male rats. Neuroendocrinology. 1984;39:330-3.

6. Blanchard RJ, Blanchard DC. Antipredator defensive behaviors in a visible burrow system. J Comp Psychol. 1989;103:70-82.

7. Tornatzky W, Miczek KA. Long-term impairment of autonomic circadian rhythms after brief intermittent social stress. Physiol Behav. 1993;53:983-93.

8. Miczek KA, Yap J], Covington HE 3rd. Social stress, therapeutics and drug abuse: preclinical models of escalated and depressed intake. Pharmacol Ther. 2008;120:102-28.

9. Haller J, Harold G, Sandi C, Neumann ID. Effects of adverse earlylife events on aggression and anti-social behaviours in animals and humans. J Neuroendocrinol. 2014;26:724-38.

10. Lopez NL, Vazquez DM, Olson SL. An integrative approach to the neurophysiological substrates of social withdrawal and aggression. Dev Psychopathol. 2004;16:69-93.

11. Blair RJR. The roles of orbital frontal cortex in the modulation of antisocial behavior. Brain Cogn. 2004;55:198-208.

12. de Almeida RMM, Ferrari PF, Parmigiani S, Miczek KA. Escalated aggressive behavior: dopamine, serotonin and GABA. Eur J Pharmacol. 2005;526:51-64.

13. Adamec RE, Stark-Adamec CI. Limbic control of aggression in the cat. Prog Neuro-Psychoph. 1983; 7:505-12.

14. Adams DB, Boudreau W, Cowan CW, Kokonowski C, Oberteuffer K, Yohay K. Offense produced by chemical stimulation of the anterior hypothalamus of the rat. Physiol Behav. 1993;53:1127-32.

15. Delville Y, De Vries G], Ferris CF. Neural connections of the anterior hypothalamus and agonistic behavior in golden hamsters. Brain Behav Evol. 2000;55:53-76.

16. Halász J, Tóth M, Kalló I, Liposits Z, Haller J. The activation of prefrontal cortical neurons in aggression--a double labeling study. Behav Brain Res. 2006;175:166-75.

17. Joppa MA, Meisel RL, Garber MA. -Fos expression in female hamster brain following sexual and aggressive behaviors. Neuroscience. 1995;68:783-92.

18. Kollack-Walker S, Watson SJ, Akil H. Social stress in hamsters: defeat activates specific neurocircuits within the brain. J Neurosci. 1997:17:8842-55

19. Kruk MR. Ethology and pharmacology of hypothalamic aggression in the rat. Neurosci Biobehav Rev. 1991;15:527-38.

20. Luiten PG, Koolhaas JM, de Boer S, Koopmans SJ. The corticomedial amygdala in the central nervous system organization of agonistic behavior. Brain Res. 1985;332:283-97.

21. Martinez M, Phillips PJ, Herbert J. Adaptation in patterns of c-fos expression in the brain associated with exposure to either single or repeated social stress in male rats. Eur J Neurosci. 1998;10:2033.

22. Siegel A, Roeling TA, Gregg TR, Kruk MR. Neuropharmacology of brain-stimulation-evoked aggression. Neurosci Biobehav Rev. 1999;23:359-89.

23. de Bruin JP, van Oyen HG, Van de Poll N. Behavioural changes following lesions of the orbital prefrontal cortex in male rats. Behav Brain Res. 1983;10:209-32.

24. Hawkins KA, Trobst, KK. Frontal lobe dysfunction and aggression: conceptual issues and research findings. Aggress Violent Beh. 2000;5:147-57.

25. Boyson CO, Holly EN, Shimamoto A, Albrechet-Souza L, Weiner LA, DeBold JF, Miczek KA. Social stress and CRF-dopamine interactions in the VTA: role in long-term escalation of cocaine self-administration. J Neurosci. 2014;34:6659-67.

26. Smagin DA, Park JH, Michurina TV, Peunova N, Glass Z, Sayed K, Bondar NP, Kovalenko IN, Kudryavtseva NN, Enikolopov G. Altered hippocampal neurogenesis and amygdalar neuronal activity in adult mice with repeated experience of aggression. Front Neurosci. 2015;9:443.

27. Vale W, Spiess J, Rivier C, Rivier J. Characterization of a 41-residue ovine hypothalamic peptide that stimulates secretion of corticotropin and beta-endorphin. Science. 1981;213:1394-7.

28. Ninan I. Synaptic regulation of affective behaviors; role of BDNF. Neuropharmacology. 2014;76:684-95.
29. Bale $T L$, Vale WW. CRF and CRF receptors: role in stress responsivity and other behaviors. Annu Rev Pharmacol Toxicol. 2004;44:525-57.

30. Koob GF. A role for brain stress systems in addiction. Neuron. 2008;59:11-34.

31. Swanson LW, Sawchenko PE, Rivier J, Vale WW. Organization of ovine corticotropin-releasing factor immunoreactive cells and fibers in the rat brain: an immunohistochemical study. Neuroendocrinology. 1983;36:165-86.

32. Chen $Y$, Bender RA, Frotscher M, Baram TZ. Novel and transient populations of corticotropin-releasing hormone-expressing neurons in developing hippocampus suggest unique functional roles: a quantitative spatiotemporal analysis. J Neurosci. $2001 ; 21: 7171-81$

33. Valentino RJ, Van Bockstaele E. Convergent regulation of locus coeruleus activity as an adaptive response to stress. Eur J Pharmacol. 2008;583:194-203.

34. Britton KT, Lee G, Vale W, Rivier J, Koob GF. Corticotropin releasing factor (CRF) receptor antagonist blocks activating and 'anxiogenic' actions of CRF in the rat. Brain Res. 1986;369:303-6.

35. Coste SC, Heard AD, Phillips TJ, Stenzel-Poore MP. Corticotropinreleasing factor receptor type 2 -deficient mice display impaired coping behaviors during stress. Genes Brain Behav. 2006;5:131-8.

36. Klampfl SM, Neumann ID, Bosch OJ. Reduced brain corticotropinreleasing factor receptor activation is required for adequate maternal care and maternal aggression in lactating rats. Eur J Neurosci. 2013;38:2742-50.

37. Klampfl SM, Brunton PJ, Bayerl DS, Bosch OJ. Hypoactivation of CRF receptors, predominantly type 2 , in the medial-posterior BNST is vital for adequate maternal behavior in lactating rats. J Neurosci. 2014;34:9665-76.

38. Sahuque LL, Kullberg EF, McGeehan AJ, Kinder JR, Hicks MP, Blanton MG, Janak PH, Olive MF. Anxiogenic and aversive effects of corticotropin-releasing factor (CRF) in the bed nucleus of the stria terminalis in the rat: role of CRF receptor subtypes. Psychopharmacology (Berl). 2006;186:122-32.

39. Backström T, Winberg S. Central corticotropin releasing factor and social stress. Front Neurosci. 2013;7:117.

40. Farrokhi C, Blanchard DC, Griebel, G, Yang M, Gonzales C, Markham C, Blanchard RJ. Effects of the CRF1 antagonist SSR125543A on aggressive behaviors in hamsters. Pharmacol Biochem Behav. 2004;77:465-9.

41. Gammie SC, Hasen NS, Stevenson SA, Bale TL, D'Anna KL. Elevated stress sensitivity in corticotropin-releasing factor receptor 2 deficient mice decreases maternal, but not intermale aggression. Behav Brain Res. 2005;160:169-77.

42. Mele A, Cabib S, Oliverio A, Melchiorri P, Puglisi-Allegra S. Effects of corticotropin releasing factor and sauvagine on social behavior of isolated mice. Peptides. 1987;8:935-8.

43. Holly EN, Boyson CO, Montagud-Romero S, Stein DJ, Gobrogge $\mathrm{KL}$, DeBold JF, et al. Episodic social stress-escalated cocaine selfadministration: role of phasic and tonic corticotropin releasing factor in the anterior and posterior ventral tegmental area. Journal of Neuroscience. 2016;36:4093-105.

44. Maynard KR, Hill JL, Calcaterra NE, Palko ME, Kardian A, Paredes $D$, et al. Functional role of BDNF production from unique promoters in aggression and serotonin signaling. Neuropsychopharmacology. 2016;41:1943-55.

45. Berton O, McClung CA, Dileone RJ, Krishnan V, Renthal W, Russo SJ, Graham D, Tsankova NM, Bolanos CA, Rios M, Monteggia LM, Self DW, Nestler EJ. Essential role of BDNF in the mesolimbic dopamine pathway in social defeat stress. Science. 2006;311:864-8.

46. Remie R. Experimental surgery. In: Krinke G], editor. The laboratory rat. London: Academic Press; 2000. p. 523-68.

47. Harris BN, Saltzman W. Effect of reproductive status on hypothalamic-pituitary-adrenal (HPA) activity and reactivity in male Californiamice (Peromyscus californicus). Physiol Behav. 2013;112-113:70-6.

48. Miczek KA, O'Donnell JM. Alcohol and chlordiazepoxide increase suppressed aggression in mice. Psychopharmacology (Berl). 1980;69:39-44.

49. Paxinos G, Franklin K. The mouse brain in stereotaxic coordinates. 2nd ed. San Diego: Elsevier Academic; 2001.

50. Haller J. Related Biochemical background for an analysis of costbenefit interrelations in aggression. Neurosci Biobehav Rev. 1995; 19:599-604.

51. Haller J, Millar S, Kruk MR. Mineralocorticoid receptor blockade inhibits aggressive behaviour in male rats. Stress. 1998:2:201-7.

52. Kruk MR, Haller J, Meelis W, de Kloet ER. Mineralocorticoid receptor blockade during a rat's first violent encounter inhibits 
its subsequent propensity for violence. Behav Neurosci. 2013;127:505-14.

53. Fish EW, Faccidomo S, Miczek KA. Aggression heightened by alcohol or social instigation in mice: reduction by the $5-\mathrm{HT}(1 \mathrm{~B})$ receptor agonist CP-94,253. Psychopharmacology (Berl). 1999;146: 391-9.

54. Finn DA, Sinnott RS, Ford MM, Long SL, Tanchuck MA, Phillips TJ. Sex differences in the effect of ethanol injection and consumption on brain allopregnanolone levels in C57BL/6 mice. Neuroscience. 2004;123:813-9.

55. Panksepp J, Burgdorf J, Beinfeld MC, Kroes RA, Moskal JR. Brain regional neuropeptide changes resulting from social defeat. Behav Neurosci. 2007;121:1364-71.

56. Joëls M, Baram TZ. The neuro-symphony of stress. Nat Rev Neurosci. 2009;10:459-66.

57. Taylor SL, Stanek LM, Ressler KJ, Huhman KL. Differential brainderived neurotrophic factor expression in limbic brain regions following social defeat or territorial aggression. Behav Neurosci. 2011:125:911-20.

58. Haller J, Kruk MR. Normal and abnormal aggression: human disorders and novel laboratory models. Neurosci Biobehav Rev. 2006;30:292-303

\section{Correspondence:}

Dr. Lucas Albrechet-Souza

Unidade de Experimentação Animal (UEA), Hospital de Clínicas de Porto Alegre

Rua Ramiro Barcelos, 2350

90035-903 - Porto Alegre, RS - Brazil

Tel: +55 (51) 3308-5066

E-mail: lucas_albrechet@hotmail.com 